\title{
From Roadblocks to a Roadmap
}

\author{
Transformative Education Pathways to Radical Change in the Midst of \\ Climate Breakdown
}

\section{Christina T. Kwauk and Radhika Iyengar}

Education has a strong role to play in strengthening our human capacity to mitigate against, and adapt to, climate change (Feinstein \& Mach, 2019; Lutz et al., 2014; Olsson et al., 2019; Wamsler et al., 2012). Studies show a strong positive correlation between education, concern for the environment, and the kinds of skills (for example, problem solving and critical thinking) and behaviors (for example, signing petitions and participating in demonstrations) that support policies, political decisions, and daily decision-making that have a positive impact on the environment (Balls, 2016; Chankrajang \& Muttarak, 2017; Chawla \& Cushing, 2007; Clery \& Rhead, 2013; Cordero et al., 2020; Franzen \& Vogl, 2013; Meyer, 2015).

Education also has ripple effects beyond the individual learner, helping to foster greater climate concern among family members and to reduce communities' vulnerabilities to the risks posed by a changing climate (Lawson et al., 2019; Muttarak \& Lutz, 2014; Striessnig et al., 2013; Save the Children, 2015). The education of girls may have an even greater ripple effect. For instance, daughters in the United States have been found to be more effective at transferring concern for the environment to their parents (Lawson et al., 2019). And when educated girls go on to become women, their empowerment and political leadership have consequential effects on the environment (Ergas \& York, 2012; Mavisakalyan \& Tarverdi, 2018; McKinney \& Fulkerson, 2015; Norgaard \& York, 2005; Nugent \& Shandra, 2009). In low- and middle-income countries, emerging research suggests that an empowering education may be key to ensuring that marginalized and vulnerable girls have the opportunity to develop the green skills necessary to participate in a green economy and to lead green social transformations of their societies (Kwauk \& Braga, 2017; Kwauk \& Casey, 2021). 
Education clearly has a strong role in climate action. But, as many critics have pointed out, people today are the most educated in human history, yet we are also the most destructive to life on this planet (Common Worlds Research Collective, 2020; Orr, 2004). Scientists have signaled that we are in the midst of a sixth mass extinction, with more than $85 \%$ of wetlands lost, $75 \%$ of our land area significantly altered, and around a million species threatened by extinction within the next few decades (Ceballos et al., 2020; IPBES, 2019). And despite the evidence of rapid ecological collapse, knowledge of the facts has been shown to be insufficient to mobilize action (Hornsey et al., 2016; Callison, 2014; Lee et al., 2015; Kahan et al., 2012; Center for Research on Environmental Decisions, 2009). This glaring gap between the education we need and the education we have has forced many of us, including millions of youth participating in \#SchoolStrikes4Climate and \#Fridays4Future, to confront the deep misalignment between education for people and for the planet.

Indeed, the urgency of the climate crisis demands that we - as education researchers, stakeholders, decision makers, and leaders - dig deep to examine our own role in enabling our global and local education systems to reproduce the values, mindsets, and world views that make possible widespread environmental injustice, carbon colonialism, and the social and economic exploitation and oppression of women, girls, Indigenous, and marginalized peoples. The global education community, guided for decades by the concept of education for sustainable development (ESD), has done too little too late to support the reorientation of our education systems to climate action, let alone to sustainable development. Critics have pointed to the failure of past and current efforts by global education leaders to move beyond "greenwashing" education, allowing, instead vested interests and neoliberal logics embedded within, and intertwined throughout, education systems to absorb the most well-intentioned efforts (Huckle \& Wals, 2015; Jickling \& Wals, 2008; Jickling et al., 2018).

For us to make up for the lost time in a rapidly closing window for action, radical transformation of our education systems is needed to catalyze the scope and scale of mindset change, paradigm shifts, and world-view expansion to address the climate crisis. Such radical reimagining could help to reorient schools away from serving a social reproduction function through standardization and assessment, and toward catalyzing social, economic, political, and ecological change through transformative learning (Boström et al., 2018; Silova et al., 2019; Sterling, 2010, 2017; Wals, 2010). 


\section{$3 \quad$ Charting an SDG 4.7 Roadmap to Radical Transformation}

It is from this point of departure that we, Radhika and Christina, convened a group of nearly two dozen academics, teachers, students, practitioners, donors, journalists, and decision makers, and over 400 participants to brainstorm pathways to disrupt education's role in perpetuating humanity's path toward socio-ecological destruction (Iyengar \& Kwauk, 2020). Our goal was to use Sustainable Development Goal (SDG) Target 4.7 to begin defining a more radical vision of education for climate action (see Table I.1).

TABLE I.1 Sustainable Development Goal 4

Goal 4. Ensure inclusive and equitable quality education and promote lifelong learning opportunities for all

Target 4.7 By 2030, ensure that all learners acquire the knowledge and skills needed to promote sustainable development, including, among others, through education for sustainable development and sustainable lifestyles, human rights, gender equality, promotion of a culture of peace and nonviolence, global citizenship and appreciation of cultural diversity and of culture's contribution to sustainable development.
Indicator 4.7.1 Extent to which

(i) global citizenship education and

(ii) education for sustainable development, including gender equality and human rights, are mainstreamed at all levels in (a) national education policies; (b) curricula; (c) teacher education; and (d) student assessment.

We convened this group in April 2020 as part of the annual meetings of the Comparative and International Education Society (CIES), which had just made a herculean effort to shift a conference planned for over 3,ooo international attendees to a virtual platform in response to the Covid-19 pandemic. At the time, nearly 1 billion students were out of school as a result of worldwide school closures, including our own young children. Little did we know that school closures would eventually reach 1.6 billion students across more than 190 countries, threatening to reverse decades of progress in increasing access to education. Nor that a year later as we prepare the launch of this volume for the next CIEs meetings we would still be battling the novel coronavirus, and more than 2 million people globally would have perished from the disease.

In the face of Covid-19 and now global efforts to "build back better", the case for the radical transformation of our education systems is even greater. Covid19 laid bare and exacerbated existing inequalities within and outside our education systems and demonstrated how education inequalities are interlocked 
with social, gender, health, economic, and geographic inequalities. While the long-term effects of this pandemic are yet to be realized, climate change threatens to throw at us ever-more-frequent shocks to our human and natural environments. Covid-19 will not be the last global disruption to life as usual. To get to a "better", more resilient place, however, we first need an understanding of where we are now and what sources of inertia we must overcome.

\section{4} Roadblocks to Quality Education in a Time of Climate Change ${ }^{1}$

To provide the context in which we wished to situate our CIES workshop (and to serve as a starting point for our readers), we began our discussion with a deep dive into five roadblocks preventing the education sector from becoming a game-changer in climate policy and action. Importantly, each of these roadblocks also offers an on-ramp to a bolder set of roadmaps to education transformation in a time of climate change. The five roadblocks are as follows.

\section{Eco-literacy Is Low on the To-Do List When Basic Literacy Is Still an Unmet Global Goal}

Low- and middle-income countries face a double burden in the context of climate change and sustainable development. Many of these countries are highly vulnerable to weather-related disasters and the negative impacts of a changing climate. At the same time, many are struggling to deliver basic education services, to address the learning crisis, and to ensure equitable access for girls, refugees, and other marginalized or minority communities. Meanwhile, upper-middle- and high-income countries in their "race to the top" are laser-focused on academic performance, examinable subjects, and high-stakes tests. As a result, few resources are left to "bring up the bottom" or to address historic educational inequities that reinforce social and economic vulnerabilities of low-income communities and communities of color.

In these contexts, addressing climate change becomes what some describe as another checkbox in a long list of priorities for resource-constrained governments (K. Hayhoe, personal communication, June 19, 2019). As a result, climate change education and ESD are viewed as complementary to, rather than fundamental to, the vision of education; additional to, rather than integrated throughout, the school curriculum. Such a perspective pits sustainability learning outcomes against academic learning outcomes, positioning the two at odds and leaving education systems to choose where to spend scarce resources. Critics have argued against such false dichotomization of learning priorities, and 
youth climate activists have pointed to the absurdity of attending school to learn facts that would be irrelevant on a planet headed for ecological collapse. This roadblock to education for climate action is thus an issue of framing.

\section{The Global Education Community Lacks a Radical Vision for Education}

The UN Decade of Education for Sustainable Development (spanning the years 2005 to 2014) promised to "integrate the principles, values, and practices of sustainable development into all aspects of education and learning" (UNEsco, n.d.). The efforts of the decade of ESD, however noble, failed to address the ethical, political, relational, and scale (for example, personal versus collective) dimensions of climate change and sustainable development; they thus fell short in their attempt to reorient education toward sustainability (Huckle \& Wals, 2015). With climate change reaching crisis levels, the global education community must confront the reality that it has spent decades "greenwashing" business as usual (Corcoran et al., 2011; Kahn, 2011).

Indeed, since environmental educators began to re-sound the alarm in the 196os about mounting environmental crises around the world, much of the global education community has continued to trumpet the neoliberal, capitalist, patriarchal values of a modern Western education system designed for the Industrial Revolution (Jickling \& Wals, 2008; Khan, 2011; Pirgmaier \& Steinberger, 2019; Silova et al., 2019; Sterling, 2017). Such a system posits learners as separate from the non-human world, and positions them to go on to control, dominate, and exploit that world as adults (Jickling \& Wals, 2008; Wals, 2012).

We see this neoliberal orientation today in the dominant framing of the learning crisis as children's inability to read or to do basic mathematics, affecting their ability to become "productive and successful adults" (see International Commission on Financing Global Education Opportunity, 2016). This framing is in contrast to a more radical framing of the learning crisis as children's inability to understand concepts like human dignity or to engage in planetary or relational thinking, thus affecting their ability not only to be responsible "to distant people and places and past and future generations", but also to be stewards of the environment and non-human life (Huckle \& Wals, 2015, p. 494; see also Rio+2o Education Group, 2012; Barry, 2005; Van Poeck et al., 2013). We also see the neoliberal framing in education discussions about how to prepare children for the future of work without a concomitant discussion of whether that work is "green" (driven on renewable energy), sustainable, inclusive, and just, or "brown" (dependent on fossil fuels), destructive, exclusive, and oppressive. All of this absence of a radical vision is in spite of the fact that the UN has already observed a decade of ESD. 


\section{Current Iterations of ESD Have an (Ine)quality Problem}

To reiterate, it's not just any kind of education to which we should be aiming. Rather, our survival on this planet requires a certain kind of education that is rooted in principles of fairness, equity, and justice, and that rejects human exceptionalism, patriarchal oppression, extractive capitalism, and unfettered economic growth (see Bangay \& Blum, 2010; Dhara \& Singh, this volume; Kwauk \& Casey, 2021; Lefay, 2006; Lotz-Sisitka et al., 2017; Pirgmaier \& Steinberger, 2019; Orr, 2004; Selby \& Kagawa, 2010; Sterling, 2004a). The Intergovernmental Panel on Climate Change (IPCC, 2018) has emphasized that:

social justice and equity are core aspects of climate-resilient development pathways that aim to limit global warming to $1.5^{\circ} \mathrm{C}$ as they address challenges and inevitable trade-offs, widen opportunities, and ensure that options, visions, and values are deliberated, between and within countries and communities, without making the poor and disadvantaged worse off. (p. 32 )

In fact, efforts by scientists to model climate-resilient development pathways could not keep global warming levels within the $1.5^{\circ} \mathrm{C}$ target if those models were characterized by the continued presence of inequality and poverty and a lack of international cooperation (IPCC, 2018). In short, social justice and equity are determinants for successful climate action. And education must enable such social change.

As Roadblock 2 indicates, more critical attention is thus needed to the quality of education (see Kwauk \& Casey, 2021). To illustrate, one study investigating the relationship between education (here, a proxy for "any kind of education" measured by completion rates, literacy, and numeracy) and the environment (measured by per capita carbon emissions) found that countries with higher levels of education tend to have higher levels of emissions, cautioning against the notion that more education as we currently know it is necessarily better (Komatsu \& Rappleye, 2018; see also McCaffrey, 2020; O’Neil et al., 2018). The study also found that countries with more collectivist orientations had lower carbon emissions than those with more individualist orientations, suggesting that education may need to take a deeper epistemological (and political) turn toward reclaiming the commons through social learning (Komatsu \& Rappleye, 2018; see also Lotz-Sisitka, 2017). Sociopsychological constructs of selfhood, identity, and collective existence with the natural world may be just as important to consider as the cognitive dimensions (the subject matter) of education (Komatsu \& Rappleye, 2018). 
But such insights into the kind(s) of education we need for people and the planet are not new. Critical scholars like Paulo Freire (2008), bell hooks (1994), and David Orr (2004), among many others, have long set into motion counter-movements against modern education systems designed to mass produce workers to "nourish the global marketplace and satisfy corporate needs" (Jickling \& Wals, 2008, p. 2). Indigenous people, feminists, and scholars of color have long pushed for intersectional approaches that spark a deep shift in consciousness about humanity's relationship with the natural world; and that also dismantle the harmful relations of power driving unsustainable, inequitable, and destructive social and socio-ecological relationships (see Gilio-Whitaker, 2019; Gudynas, 2011; Johnson \& Wilkinson, 2020; Nagendra, 2018; Shiva, 2013). Indeed, the third roadblock here is a deep systemic problem of inequality in education, which creates a structural inertia that impedes our ability to engage with issues of care, ethics, and equity that could cut to the root causes of climate change. Such inequalities strip current approaches to ESD of politics and power, and they handicap our ability to multisolve for climate change in ways that address multiple injustices and inequities (Sawin, 2018).

\section{Monitoring and Accountability Mechanisms are Oriented Toward Passive Progress}

In line with the structural inertia exhibited around the implementation of quality education for both climate action and climate justice, mechanisms to hold governments and the education sector accountable have been equally lackluster. For starters, SDG 4 (on quality education), the compass guiding the education sector for the next 10 years, does not mention climate-vulnerable or climate-affected populations as a vulnerable group; eco-literacy as a learning outcome; skills relevant for green jobs, sustainability, or planetary thinking; or education facilities powered by renewable energy. Instead, SDG 4 subsumes all climate-relevant concepts under a broader Target 4.7 focused on ESD, global citizenship education, gender equality, and human rights education.

To monitor progress toward this target, SDG Indicator 4.7.1 remains focused on prevalence rather than substance (see Table 1 ). That is, it measures whether or not policy, curriculum, teacher education, and student assessment have adopted an undefined set of ESD (and global citizenship education) concepts, rather than whether such adoption is oriented to the achievement of climate action and climate justice. Such an approach means that as data are collected, we will have a sense of the global spread of ESD, but we will know relatively little about whether education systems are actively attempting to change the status quo and tackle the climate crisis. 
Furthermore, because of conceptual, reporting, and political challenges regarding measurement, no data have been collected to date for SDG 4.7. This limitation has left decision makers and stakeholders with little or nothing from which to build policies or action plans. Researchers have attempted to fill this gap, but the one-off research studies do not offer the level of monitoring needed to hold the education community accountable for its role in climate action (see Benavot \& McKenzie, 2019; Jimenez et al., 2017; Kwauk et al., 2019; UNESCO, 2016, 2019a, 2019b).

\section{Teachers Lack the Systemic Support to Become Change Agents for Sustain- ability}

For transformation education to occur, teachers must be prepared to challenge their students to engage in critical thought and help learners to recognize and value their own experiences and expertise .... This engagement serves to interrupt current patterns of power and power relations, and contributes to a reimagining of existing worldviews, including a reconsideration of the relationships between people and planet. (Pavlova, 2013, p. 66o)

Without a doubt, if radical, transformative education for climate action is to happen, teachers will ultimately be the ones to facilitate the process. However, such recognition must be accompanied by an awareness that the onus of change is on the education system, not the teacher.

Presently, the education system is not supporting teachers (or school leadership) to lead the charge in schools. In countries like Australia, Canada, the Philippines, and the United States, teacher education institutions are not providing teachers with adequate training on climate change concepts, issues, relationships, or pedagogies; nor are they providing teachers with the in-class support, financial and pedagogical resources, creative space, and professional development opportunities to more effectively practice their craft (Competente, 2019; Drewes et al., 2018; Gwekwerere, 2014; Ferreira et al., 2009; Jickling \& Blenkinsop, 2020; Liu et al., 2015). To fill the gap in support, multilateral organizations, NGOS, and researchers have developed resources for teachers and education leaders (see Bigelow \& Swinehart, 2014; Education International, 2019; Pashby \& Sund, n.d.; UNESCO \& UNEP, 2011; UNESCO, 2011, 2013, 2018; UN CC: Learn, 2013;). Yet, without active teacher professional development networks and in-service teacher support, these resources are unlikely to have trickled down into the average classroom. 
In addition, curricular frameworks have failed in large part to integrate climate change, leaving the majority of non-science teachers around the world unsure of how to teach the topic and without time and resource to connect their subject area to it, even though they may want to teach it (Field \& Schwartzberg, 2018; Kamanetz, 2019; Survey on Climate Education, 2020; Sterling, 2004b; Taylor, 2019). In the United States, the resulting gap has been quickly filled by corporate interests and conservative actors, who not only have seeded doubt as to the scientific consensus around climate change, but also have distributed fossil fuel industry-sponsored teaching and learning materials into classrooms and have proposed legislation interfering with the teaching of climate change in schools (Brulle, 2014; Idso et al., 2015; Czajka, 2019; Glinskis, 2017; M. Mann, personal communication, July 9, 2019; Zou, 2017).

Such perverse action in the absence of proactive education leadership leaves little room for the education sector to make headway on climate change. Together with the lack of teacher training, support, and professional development, this roadblock of negligence sends a clear message to teachers that if they want to empower their students to take climate action, they are on their own.

\section{From Roadblocks to a Roadmap}

Given the complex nature of each of the five roadblocks discussed above, the global education community must look deeply and critically into what it would take to transform our education systems in order for them to realize the rapid and radical change needed in our socioeconomic and socio-ecological systems. At the conclusion of our nearly four-hour cies convening in April 2020 , it was clear that while there would be no single roadmap, the collective wisdom of dedicated teachers, impassioned students, and a global network of community organizers would ensure that there would be a common destination: to restore humanity's relationship with its planetary boundaries. But how to leverage the transformative potential of education to realize this wide-scale change in mindsets, beliefs, values, world views, and behaviors? What does the global education community need to do now to help humanity build back differently post-Covid and to survive and thrive after climate breakdown?

While this edited volume does not pretend to have the answers, it does attempt to seed radical ideas into the global education community, ideas that push past the sector's conceptual, systemic, and structural roadblocks; that situate a new purpose of education within our planetary boundaries; that 
transform education as we currently know it; and that enable the education sector to be a game-changer in climate action. This volume picks up and carries forward the discussion from April 2020 with some of the same discussants and with many new ones. It also carries forward the spirit of our CIES workshop to bring "outside" voices into what typically is a space reserved for education researchers and academic theorists (Iyengar \& Kwauk, 2020). The volume thus includes perspectives that span multiple continents, disciplines, and positionalities within the education system - from teachers to students to practitioners to leadership to academics. It brings to attention case studies, gives overviews of strategic frameworks, reports lessons from the field, provides practical examples, and gives voice to advocates for climate action.

The volume uses the five roadblocks to structure and provoke five discussions toward transformative pathways to radical change, with the caveat that all these discussions are interdependent, intertwined with issues raised by the others. Such is the systemic nature of the five roadblocks and their solutions.

\subsection{Part 1: Toward Education for Climate Action as the Priority}

The volume begins with a set of chapters addressing the first roadblock, moving us toward a vision in which education for climate action is the priority that ties together and serves as the conduit for the achievement of all other priorities in education. To start, Alyssa Dougherty, a student at the University of California, Santa Barbara, reflects on her education in the United States, on Covid-19, and on how schools in the United States have left students to educate themselves about the most critical issues facing humanity, including climate change. Her call for the integration of climate change education into the curriculum lays out the demands of millions of students striking around the world for their schools to provide at minimum a basic education in climate science (see Mock COP, 202O).

Nidhi Thakur takes us next to understand what school leadership can do to push for climate action in the absence of broader curricular reform. Through a case study of an elementary school principal in New Jersey, and the students and parents behind him, Thakur illustrates how education leaders can prioritize sustainability in ways that become teachable moments for the more holistic development of students, and that this approach can go on to have ripple effects throughout the community. Although the case study is about a specific school's move away from single-use plastics, it illustrates how schools that "walk the talk" on sustainability create a new hidden curriculum that in many ways can be more powerful than the official curriculum.

The next chapter, by Kristen Hargis, Marcia McKenzie, and Isabelle LeVertChiasson, extends this point further with their discussion of a "whole school" 
approach to climate change education. This approach is the epitome of abandoning the checkbox approach to ranking eco-literacy among a host of other educational priorities in favor of situating it throughout all aspects of the institution - school governance, teaching and learning, facilities and operations, and community partnerships. Their chapter, which evaluates the Getting Climate-Ready pilot program in Canada, affirms research from the United Kingdom, Australia, Sweden, and other countries that suggest that if schools are able to adopt sustainability as an orienting principle throughout both the curriculum and the organization of the school, not only do teachers teach about sustainability and climate change, but also school quality is improved and teachers are better supported (Barratt Hacking et al., 2010; Læssøe et al., 2009; McMillin \& Dyball, 20o9; Mogren et al., 2019).

Keeping our focus on Canada, Irena Creed, Meghna Ramaswamy, and their co-authors lay out a series of design aspirations meant to enable universities to become a hub for radical thinking and transformative action in their surrounding communities. Arguing that universities are a microcosm of society, the authors offer a useful entry point for conceptualizing education for climate action at scale. In particular, scholars investigating pathways to sustainability transformation suggest that there may be a particular population scale of action - a "sweet spot" - in which the collective ability to take meaningful local action and achieve global impact is optimized (Bhowmik et al., 2020). They suggest that such a sweet spot for climate action is at a population scale of between 10,000 and 100,000 people - or roughly at the scale of community, metacommunities (groups of communities), or cities -depending on the context. When applied to the education system, an equivalent would be a school district, a large university, or a network of independent schools. Creed, Ramaswamy, and co-authors' chapter could serve as a useful starting point to scale education for climate action across school districts or state university systems around the world.

\subsection{Part 2: Toward a More Radical, Transformative Vision of Education for Climate Action}

The second part responds to Roadblock 2 by moving us toward a more radical vision of education for climate action. Alexander Leicht and Won Jung Byun start this part with a deeper look into UNESCO's new framework for education for sustainable development (ESD for 2030). This framework aims to breathe new life into the ESD agenda, basing its ambitiousness on both the scale of social transformation needed to address the mounting climate crisis and the growing international policy convergence around the importance of education for climate action. Leicht and Byun provide a historic context for the ESD 
agenda, and they illuminate where the global community currently stands in relation to advancing a kind of education that can help achieve not only Target 4.7 but also our broader Sustainable Development Goals. Importantly, UNESCO'S ESD for 2030 framework begins to push the global education community to critically examine the tenuous and unsustainable relationship between current models of economic growth and human and planetary well-being, and education's role in maintaining or disrupting this status quo. Such a stance is a radical departure from education as we know it, which more often than not tends to dissociate our present economic systems and practices from their social and ecological consequences. The chapter aims to fill important gaps in policy and practice by presenting front and center a more transformative vision for ESD.

Drawing on a perspective from global citizenship education (GCED), Ricardo Roemhild and William Gaudelli help us further define what a radically different approach to education could look like, one centered on concepts of human rights and environmental justice. Indeed, they demonstrate how a GCED-informed education for climate action is essential to grounding our focus in the sociological dimensions of climate change, a focus that can help pave the way to equitable climate action. Furthermore, beyond providing entry points into critical issues of climate justice, Roemhild and Gaudelli illustrate how a pairing of GCED with a future-focused orientation creates important conduits for disrupting what we take for granted and allows for the critique of what we have come to accept as normal about our present fossil-fuel driven economy. Such an approach lends itself not only to developing in learners important cognitive and socioemotional skills, but also to broadening their world view; increasing their concern for the interconnectedness of local and global; and setting them on a path toward civic engagement, which is at the heart of climate action and climate justice.

Following next, Chirag Dhara and Vandana Singh take us into a direct confrontation with "the elephant in the room": the incompatibility between sustainability and development - particularly development characterized by the logic of unfettered economic growth. Drawing on their backgrounds in physics and climate science, Dhara and Singh help us come to a more complete and coherent understanding of the complicit role that education -characterized by the logics of SDG 4.7 - has played in this inherent tension having been both ignored and perpetuated. The authors create for us an entry point through which to question our existing educational paradigms, and to question what we deem to be "sustainable" practices and behaviors for teaching to students. Their chapter helps us to define the minimum bar we should be setting for education to be truly considered "radical". That bar is the biophysical parameters - the boundaries - of our planet; we should accept nothing less. 
Switching gears but not our direction, Richa Sharma's chapter brings to our visionary exercise a student perspective. What is a radical, transformative education for climate action if it does not respond to students' needs and demands? The millions of student and youth activists who have skipped school around the world to protest our collective inaction on climate change have made clear that an education that does not prepare us to face the challenges wrought by climate change is an irrelevant education. Such mobilization sends a powerful message: the centrality of our human relationship with the natural world in this project we call education. And it highlights how far removed and how untethered our education has become from this message. Sharma's examination of the motivations behind youth climate activism in the United Kingdom demonstrates for us that education for climate action cannot be radical or transformative if it does not also entail social change and social justice. More important, if our approach to education is not intersectional and doesn't highlight the intersectionality of climate change and its impacts, it will miss the mark.

\subsection{Part 3: Toward (E)quality in Education for Climate Action}

The third part responds to the need to focus on the quality of education for climate action; that is, not just any education about climate change will suffice. More important, this part helps us understand that a quality education must be defined as one that not only engenders climate action, but also aims to achieve climate justice, through two avenues: through the actions that are engendered as a result of that education and through the epistemological and pedagogical approaches to education that are employed. Indeed, as this part illustrates, we radically transform how we approach education for climate action when we bring in the affective, emotional, and psychosocial dimensions of learning; when we touch on issues of power, privilege, vulnerability, and risk in relation to climate change and the teaching of it; and when we inform our pedagogies with diverse forms of knowing and being with others in the world. This part moves us toward understanding that (quality) climate change education is not just about (good) science. It is about consciousness-raising and disruption, which are experiences that go beyond education as we currently know it.

Vandana Singh begins our exploration of quality education for climate action by walking us through a transdisciplinary, justice-centered pedagogical approach to teaching climate change to general physics students in a US university. Having spent nearly a decade refining this pedagogy, she explains how each step in her approach responds to a barrier to climate change education, illustrating how each step generates a transformative learning moment even in the context of a physical sciences classroom - a space not typically associated with the grappling of issues of inequality, poverty, and social justice. Her 
chapter offers a forceful critique of our siloed approach to education with its traditional disciplines, which function to fragment knowledge (and disconnect it from issues of feelings, relationships, and power) and thus prevent us from seeing complex systems for what they are. Because she teaches climate change in a physics classroom through a transdisciplinary approach that embraces the psychosocial dimensions of learning, her students are able to fully understand - as affective beings - the interrelationships of the biophysical world and our human world.

Next, Yovita Gwekwerere and Overson Shumba take us to Zambia and Zimbabwe to demonstrate how quality education for climate action must be contextually defined and must draw upon Indigenous knowledge, lest climate change education or ESD reproduce European colonial legacies of knowing and learning, which are still all too real in Southern African education systems. Specifically, Gwekwerere and Shumba discuss how the African concept of Ubuntu is critical to grounding an African approach to education for climate action in the epistemological and ontological orientations of African thought, and to making an education for climate action relevant to students' lived experiences and ways of knowing, doing, being, and being with others. Their analysis of the national curriculum frameworks of both countries goes on to reveal that despite the value of Ubuntu, both frameworks fall far short of providing teachers with the necessary scaffolding (both technical and philosophical) to connect these concepts to local ways of knowing. Moreover, Eurocentric framing of climate change education and ESD concepts are nearly incomprehensible to teachers, translated into a knowledge system so disconnected from local ways of knowing that climate change education and ESD in Zambia and Zimbabwe have become untethered to a reality that is already marked by regular experience of climate emergencies. Gwekwerere and Shumba's chapter is a stark reminder that quality education does not just mean issues of climate justice, fairness, and equity are integrated as objects of critical reflection en route to consciousness-raising, but also that the very project of education must also work to disrupt and counter injustice, oppression, exclusion, and inequity.

Shifting to Guatemala, Elisa Hartwig provides us with a counterexample one that illustrates how the project of education itself must be radically transformed through a participatory, inclusive, and context-responsive process of co-creation, with community members and teachers, in order for the process of teaching and learning for climate action to be of quality and relevance. Recounting her experiences at Antigua Green School, Hartwig lays out a reflection, critical for our purposes, on the participatory process she and her school community undertook to redevelop the school's curriculum and to reorient its objectives toward a more radical vision of education for climate action. Her 
chapter provides a case study and model that other education institutions can, and should, learn from and adapt. Importantly, Hartwig's chapter also raises the issue of the critical role that teachers play in translating these ideas of quality education for climate action into practice. She illustrates also how such teacher reorientation does not come without resistance, how challenging it is for teachers to unlearn pedagogical practices and educational epistemologies in a system that provides ample incentives to stay with pedagogies that achieve standardization rather than transformation.

Tara Stafford Ocansey and Emmanuel Nuetey Siakwa's chapter takes our discussion of (e)quality in education for climate action into a non-formal community-based education program serving women in eastern Ghana. Ocansey and Siakwa demonstrate how achieving equality through education for climate action means also ensuring that those who have been excluded from their education systems because of poverty, harmful gender norms, and other forms of marginalization are provided with the opportunity to gain the knowledge and skills that increase their adaptive capacity and climate resilience. This case study shows that lifelong learning and intersectionality are critical dimensions of climate adaptation and sustainable development, and that when applied to education for climate action they can open the door to "multisolving" with regard to multiple injustices and inequities, including those that climate change exacerbates. In this case, Ocansey and Siakwa demonstrate how an intersectional approach to education for climate action can multisolve with regard to significant development challenges, such as gender equality, waste management, public health, and livelihoods. Such an example pushes us to expand our expectations and conceptions of what outcomes a quality education for climate action can ultimately achieve.

\subsection{Part 4: Toward Greater Accountability in Education for Climate Action}

The fourth part addresses the fourth roadblock, helping to spur discussions that move us toward greater accountability in education for climate action. But to whom is the education system accountable? To what end is the vision to be achieved? And what needs to be measured to track progress? Millions of youth around the world have sent a clear message that the ultimate goal is not only our collective survival on this planet but also the flourishing of future generations of humankind, and it is to the planet and to those generations that we must be held accountable. To measure progress toward this radical vision of education, we must be measuring whether education leads not only to knowledge gained and behaviors changed, but also to actions designed to achieve systems change, gender equality, Indigenous sovereignty, intergenerational 
and climate justice, and so on. We must measure what we value, not value what we measure.

In this spirit, Part 4 includes the reflections of three students - twelfth grader Kiana Carlisle, college student Isabelle Seckler, and seventh grader Ishaan Bharadwaj - who represent the community to whom governments, ministries of education, and the global education community should be held to account. This part focuses on youth's stories of their own interests in, desire for, and demand for, a transformational education that strengthens their own capacities and those of their families and their communities to adapt to, and mitigate against, climate change. Stories such as these should frame all attempts to reorient our monitoring and accountability mechanisms in the direction of radical change.

In her chapter, Carlisle discusses her personal efforts to fill the void left by her schooling. As she writes, "With a lack of information, there is a lack of conversation". And with a lack of conversation, we risk spiraling into a climate silence that ultimately leads to climate inaction (Maibach et al., 2016). Carlisle's transformative journey toward environmental stewardship and climate activism from a place of climate curiosity is not only a process that schools should aim to recreate, but also a process on which they should be evaluated.

Seckler's chapter shifts to a highlighting of the interdisciplinary nature of climate action, and thus the multidimensional outcomes that must form the standard for monitoring education systems. Her chapter suggests that if we are to realize the radical vision of human survival and human flourishing on this planet, we must rethink how we deliver education as siloed subject matter - or, as Seckler writes, as "standard intro-level lectures that most first year students enroll in" - and transform that into the interdisciplinary problem-based learning that can unleash students' curiosity beyond the four walls of their classrooms and empower them to take "agency over acquiring knowledge". As Seckler reflects on her own education for climate action, what clearly emerges is the important combination of systems thinking, curiosity, and passion that she honed over time. If such a combination of multidimensional learning outcomes were conceptualized as key - as what every education should provide - we would be well on our way to addressing society's most wicked problems.

In the next chapter, Bharadwaj provides another example of the potential of education for climate action to transform not only the individual learner, but also one's family and one's community, and in ways that have real consequences for the environment. Although Bharadwaj writes lightheartedly about his Thanksgiving eco-challenge, to rid the iconic holiday dinner of plastic, his reflection demonstrates the important intergenerational effect that children can have on their parents and elders - how reaching one student can quickly 
mushroom to many (Lawson et al., 2019). Such ability to not only communicate the urgency of climate change but also to inspire behavioral change is just what is needed to solve this climate crisis.

Although their stories are awe-inspiring, Carlisle's, Seckler's and Bharadwaj's chapters also paint a disappointing picture of what is lacking in education as we currently know it. Their stories indicate that for all of them, getting education for climate action was largely self-driven or spurred on from outside the formal curriculum. If we want the stories of these three young individuals to become the norm rather than the exception, we must create a radically different set of incentives for the education system. Rather than accepting standardized measures of achievement, we must value the transformative process, multidimensional outcomes (including systems thinking, curiosity, passion, and communication), and social and behavioral change. As long as these goals are "nice to haves" rather than "must haves", our radical vision of education for climate action will remain a dream rather than a reality.

\subsection{Part 5: Toward Empowering Teachers as Agents of Climate Action}

Finally, to address the fifth roadblock, the fifth part moves us toward empowering teachers as agents of climate action. Drawing on his own experiences as a teacher in Malaysia and complementing this account with an analysis of relevant literature, Pravindharan Balakrishnan in his chapter reflects on how to leverage existing entry points within the Malaysian education system to strengthen teacher capacity and expand teachers' opportunities to deliver education for climate action. Balakrishnan's chapter raises the importance - in the face of a strong exam-oriented education culture, a highly centralized education system, and uneven implementation of environmental education - of leadership's providing, from the top, the right signals, which then convey to the rest of the education system the importance of teachers' integrating climate change into the syllabus, rather than their treating it as an elective subject or consigning it to one-off green-themed school competitions. Such prioritization from the top - addressing Roadblock 1 as well - could then help to unlock funding, resources, and opportunities to strengthen teacher capacity to help move education for climate action in Malaysia away from greenwashing to transformative change.

Moving to India, we have Haein Shin and Srinivas Akula picking up the threads from Balakrishnan's chapter and centering on the perspectives of educators themselves as they think about how best to strengthen their capacity to engage in higher quality education for climate action (in this context, referred to as environmental education). Shin and Akula discuss how a solarpowered Information and Communications Technology Center embraced 
the opportunity to provide teachers in-depth training on inquiry- and discussion-based learning techniques, and to give continued support in their use. The authors found a demonstrable increase not only in the amount of time the teachers spent on environmental topics, but also in the degree to which the teachers applied lessons to the young women students' daily lives. Not only did such improvements in pedagogy bring environmental concepts to life for students, but they also created in them an awareness and curiosity about how environmental topics manifest in daily life. This new awareness then stimulated a personal connection to environmental issues and a drive to take responsive action to remedy their root causes. Shin and Akula's chapter demonstrates the importance of teacher training and pedagogical innovation in helping teachers seed change in others.

Estefanía Pihen González's chapter helps to refine further the impact that empowered teachers can have on motivating students and other educators to live more sustainably. Her chapter provides practical examples from around the Americas and Asia of schools' attempting to remove structural roadblocks (ranging from improper curricular integration to resistant parents) that prevent teachers from fully embracing their roles as change agents for sustainability and climate action. Her chapter speaks to the importance of supportive school leadership in creating an encouraging and enabling environment that builds teachers' professional resilience and thus their willingness to try new ways of teaching the curriculum. Specifically, her case study of Guanacaste International Academy in Costa Rica provides a rare peek behind the curtains when it comes to engaging teachers and school leadership in the process of breaking through preconceived notions of what education should look like and arriving at new ways of educating students for climate action. What started as a school's experiment with integrated lesson plans through an Issue-Academic-Standard (IAS) method has itself become "standard" practice.

Closing this part and our authors' contributions to the volume is a chapter by William Bertolotti, a teacher at Plainedge High School in the state of New York and mentor to author Bharadwaj from Part 4. Part philosophy, part call to action, Bertolotti's reflections on the questions that drive his teaching - How can I nurture my students' talents? How can I empower them? How can I seed in them compassion that grows into a desire for social change? - remind us that strengthening teacher capacity and removing structural and systemic roadblocks to education for climate action are about unencumbering teachers so that they can perform well the task of social-ecological transformation. Recognizing the disruptions that Covid-19 triggered in 2020 and the chronic eco-anxiety of an undisrupted climate crisis, Bertolotti closes his chapter with a powerful message: 
Even now, when our students are confronted with so many dire and starkly brutal signs of the ills of the world, they endure, they persevere, they protest, they grow rapidly into adulthood. As teachers, few things are as heartwarming and inspiring as the raw power inherent in each student - a potential waiting to be honed - and a reminder that in every student's ability to succeed resides also our affirmative duty as educators to continue nurturing humanity's greatest potential. May the successful advocacy and stewardship of the next generation be our greatest legacy.

Continued inertia within the education system will impede our capacity to respond and to act at the pace and scale required to reverse our course toward climate catastrophe. This volume, while beginning with five roadblocks to quality education in the midst of a climate crisis, aims to move us collectively past these barriers. This book is a response to inaction by the education sector, and it aims to channel the energy from our cies Workshop at the beginning of this Covid-19 pandemic into an assemblage of pathways or roadmaps for others to use to chart a more radical path to an education that ensures not only the survival of humankind, but also the flourishing of future generations on this planet. It is high time for education leaders to heed the message of millions of schoolchildren striking around the world and to ask themselves what they can do to transform the education of today into the education that we need.

\section{Note}

1 This section is adapted from the report "Roadblocks to Quality Education in a Time of Climate Change" (Kwauk, 2O2O).

\section{References}

Balls, E. (2016). Analysing key debates in education and sustainable development in relation to ESD practice in Viet Nam. International Journal of Development Education and Global Learning, 8(1), 21-37.

Bangay, C., \& Blum, N. (2010). Education responses to climate change and quality: Two parts of the same agenda? International Journal of Educational Development, 30 , $359-368$.

Barratt Hacking, E., Scott, E. W., \& Lee, E. (2010). Evidence of impact of sustainable schools. Department for Children, Schools, and Families. 
Barry, J. (2005). Resistance is fertile: From environmental to sustainability citizenship. In D. Bell \& A. Dobson (Eds.), Environmental citizenship: Getting from here to there? (pp. 21-48). MIT Press.

Benavot, A., \& McKenzie, M. (2019). The transitions project: Education for sustainable development and global citizenship from pre-primary to secondary education (Technical report). UAS Albany and The Sustainability and Education Policy Network.

Bhowmik, A. K., McCaffrey, M. S., Ruskey, A., Frischmann, C., \& Gaffney, O. (2020). Powers of 10: Seeking 'sweet spots' for rapid climate and sustainability actions between individual and global scales. Environmental Research Letters, 15(9).

Bigelow, B., \& Swinehart, T. (2014). A people's curriculum for the Earth: Teaching climate change and the environmental crisis. Rethinking Schools.

Boström, M., Andersson, E., Berg, M., Gustafsson, K., Gustavsson, E., Hysing, E., ... Öhman, J. (2018). Conditions for transformative learning for sustainable development: A theoretical review and approach. Sustainability, 10(12), 4479.

Brulle, R. J. (2014). Institutionalizing delay: Foundation funding and the creation of the US climate change counter-movement organizations. Climatic Change, 122, 681-694.

Callison, C. (2014). How climate change comes to matter: The communal life of facts. Duke University Press.

Ceballos, G., Ehrlich, P. R., \& Raven, P. H. (2O20). Vertebrates on the brink as indicators of biological annihilation and the sixth mass extinction. PNAS, $117(24), 13596-13602$.

Center for Research on Environmental Decisions. (2009). The psychology of climate change communication: A guide for scientists, journalists, educators, political aides, and the interested public.

Chankrajang, T., \& Muttarak, R. (2017). Green returns to education: Does schooling contribute to pro-environmental behaviours? Evidence from Thailand. Ecological Economics, 131, 434-448.

Chawla, L., \& Cushing, D. F. (2007). Education for strategic environmental behavior. Environmental Education Research, 13, 437-452.

Clery, E., \& Rhead, R. (2013). Education and attitudes towards the environment. Background paper prepared for the Education for All Global Monitoring Report 2013/4. UNESCO.

Common Worlds Research Collective. (2020). Learning to become with the world: Education for future survival. Background paper for the Futures of Education Initiative. UNESCO.

Competente, R. J. T. (2019). Pre-service teachers' inclusion of climate change education. International Journal of Evaluation and Research in Education, 8(1), 119-126.

Corcoran, P. B., Weakland, J. P., \& Wals, A. E. J. (Eds.). (2011). Envisioning futures for environmental and sustainability education. Wageningen Academic Publishers.

Cordero, E. G., Centeno, D., \& Todd, A. M. (2020). The role of climate change education on individual lifetime carbon emissions. PLoS ONE, 15(2). 
Czajka, K. (2019). States are introducing bills that could prevent teachers from advocating for climate change. Pacific Standard. https://psmag.com/news/state-billscould-prevent-teachers-from-advocating-for-climate-change

Drewes, A., Henderson, J., \& Mouza, C. (2018). Professional development design considerations in climate change education: Teacher enactment and student learning. International Journal of Science Education, 40(1), 67-89.

Education International. (2019). Education: A powerful tool for combatting climate change: A guide for education unions and educators. https://issuu.com/ educationinternational/docs/ie_education_a_power_full_tool_for_

Ergas, C., \& York, R. (2012). Women's status and carbon dioxide emissions: A quantitative cross-national analysis. Social Science Research, 41(4), 965-976.

Feinstein, N. W., \& Mach, K. J. (2019). Three roles for education in climate change adaptation. Climate Policy, 2o(3), 1-6.

Ferreira, J., Ryan, L., Davis, J., Cavanagh, M., \& Thomas, J. (2009). Mainstreaming sustainability into pre-service teacher education in Australia. Macquarie University.

Field, E., \& Schwartzberg, P. (2018). Canada, climate change and education: Opportunities for public and formal education. http://lsf-lst.ca/media/National_Report/ Executive_Summary_Slides_Climate_Change.pdf

Franzen, A., \& Vogl, D. (2013). Two decades of measuring environmental attitudes: A comparative analysis of 33 countries. Global Environmental Change, 23(5), 10011008.

Freire, P. (2008). Pedagogy of the oppressed. Continuum International. (Original work published 1970)

Gilio-Whitaker, D. (2019). As long as grass grows: The indigenous fight for environmental justice, from colonization to Standing Rock. Beacon.

Glinskis, E. (2017). A new wave of state bills could allow public schools to teach lies about climate change. Vice News. https://www.vice.com/en_us/article/qvz593/sixstates-trying-to-pass-climate-denial-in-education-legislation

Gudynas, E. (2011). Buen vivir: Today's tomorrow. Development, 54(4), 441-447.

Gwekwerere, Y. (2014). Pre-service teachers' knowledge, participation and perceptions about environmental education in schools. Australian Journal of Environmental Education, 30(2), 198-214.

hooks, b. (1994). Teaching to transgress: Education as the practice of freedom. Routledge. Hornsey, M. J., Harris, E. A., Bain, P. G., \& Fielding, K. S. (2016). Meta-analyses of the determinants and outcomes of belief in climate change. Nature Climate Change, 6 , $622-626$.

Huckle, J., \& Wals, A. E. J. (2015). The UN decade of education for sustainable development: Business as usual in the end. Environmental Education Research, 21(3), 491-505.

Idso, C., Carter, R., \& Singer, F. (2015). Why scientists disagree about global warming (2nd ed.). Heartland Institute. 
International Commission on Financing Global Education Opportunity. (2016). The learning generation: Investing in education for a changing world.

IPBES [Intergovernmental Science-Policy Platform on Biodiversity and Ecosystem Services]. (2019). Global assessment report on biodiversity and ecosystem services of the Intergovernmental Science-Policy Platform on Biodiversity and Ecosystem Services.

IPCC [Intergovernmental Panel on Climate Change]. (2018). Summary for policymakers. In V. Masson-Delmotte et al. (Eds.), Global warming of $1.5^{\circ} \mathrm{C}$. An IPCC Special Report on the impacts of global warming of $1.5^{\circ} \mathrm{C}$ above pre-industrial levels and related global greenhouse gas emission pathways, in the context of strengthening the global response to the threat of climate change, sustainable development, and efforts to eradicate poverty. World Meteorological Organization.

Iyengar, R., \& Kwauk, C. (2020). Bringing in 'outside' voices: Reflections on sustainability dialogues and conference planning. Comparative Education Review, 64(4), 761-764.

Jickling, B., \& Blenkinsop, S. (2020). Wilding teacher education: Responding to the cries of nature. Canadian Journal of Environmental Education.

Jickling, B., Blenkinsop, S., Timmerman, N., \& De Dannan Sitka-Sage, M. (Eds.). (2018). Wild pedagogies: Touchstones for re-negotiating education and the environment in the Anthropocene. Palgrave Macmillan.

Jickling, B., \& Wals, A. E. J. (2008). Globalization and environmental education: Looking beyond sustainable development. Journal of Curriculum Studies, 40(1), 1-21.

Jimenez, J. D., Lerch, J., \& Bromley, P. (2017). Education for global citizenship and sustainable development in social science textbooks. European Journal of Education, $52(4), 460-476$.

Johnson, A. E., \& Wilkinson, K. K. (Eds.). (2020). All we can save: Truth, courage, and solutions for the climate crisis. One World.

Kahan, D. M., Peters, E., Wittlin, M., Slovic, P., Ouellette, L. L., Braman, D., \& Mandel, G. (2012). The polarizing impact of science literacy and numeracy on perceived climate change risks. Nature Climate Change, 2, 732-735.

Kahn, R. (2011). How should global climate change the climate of our conversation in education? http://sustainability.psu.edu

Komatsu, H., \& Rappleye, J. (2018). Will SDG4 achieve environmental sustainability? Center for Advanced Studies in Global Education Working Paper \#4. Arizona State University.

Kwauk, C. (2020). Roadblocks to quality education in a time of climate change. Brookings. https://www.brookings.edu/research/roadblocks-to-quality-education-in-a-timeof-climate-change/

Kwauk, C., \& Braga, A. (2017). Three platforms for girls' education in climate strategies. Brookings.

Kwauk, C., \& Casey, O. (2021). A new green learning agenda: Approaches to quality education for climate action. Brookings. 
Kwauk, C., Cooke, J., Hara, E., \& Pegram, J. (2019). Girls' education in climate strategies: Opportunities for improved policy and enhanced action in Nationally Determined Contributions. Working Paper 133. Brookings.

Læssøe, J., Schnack, K., Breiting, S., \& Rolls, S. (2009). Climate change and sustainable development: The response from education. International Alliance of Leading Education Institutes.

Lawson, D. F., Stevenson, K. T., Nils Peterson, M., Carriers, S. J., Strnad, R. L., \& Seekamp, E. (2019). Children can foster climate change concern among their parents. Nature Climate Change, 9, 458-462.

Lee, T. M., Markowitz, E. M., Howe, P. D., Ko, C.-Y., \& Leiserowitz, A. A. (2015). Predictors of public climate change awareness and risk perception around the world. Nature Climate Change, 5, 1014-1020.

Lefay, R. (2006). An ecological critique of education. International Journal of Children's Spirituality, $11(1), 35^{-45}$.

Liu, S., Roehrig, G., Bhattacharya, D., \& Varma, K. (2015). In-service teachers' attitudes, knowledge and classroom teaching of global climate change. Science Educator, $24(1), 12-22$.

Lotz-Sisitka, H. (2017). Education and the common good. In B. Jickling \& S. Sterling (Eds.), Post-sustainability and environmental education: Remaking education for the future (pp. 63-76). Palgrave Macmillan.

Lotz-Sisitka, H., Mukute, M., Chikunda, C., Baloi, A., \& Pesanayi, T. (2017). Transgressing the norm: Transformative agency in community-based learning for sustainability in Southern African contexts. International Review of Education, 63, 897-914.

Lutz, W., Muttarak, R., \& Striessnig, E. (2014). Universal education is key to enhanced climate adaptation. Science, 346, 1061-1062.

Maibach, E., Leiserowitz, A., Rosenthal, S., Roser-Renouf, C., \& Cutler, M. (2016). Is there a climate "spiral of silence" in America? Yale Program on Climate Change Communication.

Mavisakalyan, A., \& Tarverdi, Y. (2018). Gender and climate change: Do female parliamentarians make difference? GLO Discussion Paper 221.

McCaffrey, M. (2020). Education's dark shadow and (how to enlighten it). Unpublished paper.

McKinney, L., \& Fulkerson, G. (2015). Gender equality and climate justice: A cross-national analysis. Social Justice Research, 28, 293-317.

McMillin, J., \& Dyball, R. (20o9). Developing a whole-of-university approach to educating for sustainability: Linking curriculum, research and sustainable campus operations. Journal of Education for Sustainable Development, 3, 55-64.

Meyer, A. (2015). Does education increase pro-environmental behavior? Evidence from Europe. Ecological Economics, 116, 108-121. 
Mock COP. (2020, December 1). Declaration of the Mock Conference of the Parties 26. https://www.mockcop.org/wp-content/uploads/2020/11/20200112-MOCK-COPDeclaration.pdf

Mogren, A., Gericke, N., \& Scherp, H. (2019). Whole school approaches to education for sustainable development: A model that links to school improvement. Environmental Education Research, 25(4), 508-531.

Muttarak, R., \& Lutz, W. (2014). Is education a key to reducing vulnerability to natural disasters and hence unavoidable climate change? Ecology and Society, 19(1), 42.

Nagendra, H. (2018). The global south is rich in sustainability lessons that students deserve to hear. Nature, 557 (7706), 485-488. https://www.nature.com/articles/ d41586-018-05210-o

Norgaard, K., \& York, R. (2005). Gender equality and state environmentalism. Gender \& Society, 19(4), 506-522.

Nugent, C., \& Shandra, J. M. (2009). State environmental protection efforts, women's status, and world polity. Organization \& Environment, 22, 209-229.

Olsson, D., Gericke, N., \& Chang Rundgren, S. N. (2016). The effect of implementation of education for sustainable development in Swedish compulsory schools: Assessing pupils' sustainability consciousness. Environmental Education Research, 22(2), 176-202.

O’Neil, D. W., Fanning, A. L., Lamb, W. F., \& Steinberger, J. K. (2018). A good life for all within planetary boundaries. Nature Sustainability, 1, 88-95.

Orr, D. (2004). Earth in mind: On education, environment, and the human prospect. Island Press. (Original work published 1994)

Pashby, K., \& Sund, L. (n.d.). Teaching for sustainable development through ethical global issues pedagogy: A resource for secondary teachers. Manchester Metropolitan University. https://www.mundu.dk/wp-content/uploads/Karen-Pashby-LouiseSund-EthicalGlobalIssues.pdf

Pavlova, M. (2013). Towards using transformative education as a benchmark for clarifying differences and similarities between environmental education and education for sustainable development. Environmental Education Research, 19(5), 656-672.

Pirgmaier, E., \& Steinberger, J. K. (2019). Roots, riots, and radical change: A road less travelled for ecological economics. Sustainability, n1(7), 1-18.

Rio+20 Education Group. (2012). The education we need for the world we want. http://rio2o.net/en/propuestas/the-education-we-need-for-the-world-we-want/

Save the Children. (2015). Mitigating Ethiopia's drought impacts on children through education. https://resourcecentre.savethechildren.net/node/12664/pdf/mitigating ethiopias_drought_impacts_on_children_through_education_may_2016.pdf

Sawin, E. (2018). The magic of "multisolving": Six principles and practices to un-lock cross-sectoral collaboration. Stanford Social Innovation Review. https://ssir.org/ articles/entry/the_magic_of_multisolving 
Selby, D., \& Kagawa, F. (2010). Runaway climate change as challenge to the 'closing circle' of education for sustainable development. Journal of Education for Sustainable Development, 4(1), 37-50.

Shiva, V. (2013). Everything I need to know I learned in the forest. NAMTA Journal, $38(1)$, $273-276$.

Silova, I., Rappleye, J., \& Komatsu, H. (2019). Measuring what really matters: Education and large-scale assessments in the time of climate crisis. ECNU Review of Education, $2(3), 342-346$.

Sterling, S. (2004a). Sustainable education: Re-visioning learning and change. Schumacher Briefings, 6. Green Books.

Sterling, S. (2004b). The ecological and environmental dimensions of the holistic curriculum. In Encyclopedia of life support systems. EOLSS Publishers.

Sterling, S. (2010). Transformative learning and sustainability: Sketching the conceptual ground. Learning and Teaching in Higher Education, 5, 17-33.

Sterling, S. (2017). Assuming the future: Repurposing education in a volatile age. In B. Jickling \& S. Sterling (Eds.), Post-sustainability and environmental education: Remaking education for the future (pp. 31-45). Palgrave Macmillan.

Striessnig, E., Lutz, W., \& Patt, A. G. (2013). Effects of educational attainment on climate risk vulnerability. Ecology and Society, 18(1), 16.

Survey on climate education: Results. (2020). School Education Gateway, Erasmus+. https://www.schooleducationgateway.eu/en/pub/viewpoints/surveys/survey-onclimate-education.htm

Taylor, M. (2019). Teachers want climate crisis training, poll shows. The Guardian. https://www.theguardian.com/environment/2019/jun/21/teachers-want-climatecrisis-training-poll-shows

UN CC: Learn. (2013). Resource guide for advanced learning on integrating climate change in education at primary and secondary level. UNITAR.

UNESCO. (n.d.). UN decade of ESD. https://en.unesco.org/themes/educationsustainable-development/what-is-esd/un-decade-of-esd

UNESCO. (2011). Climate change starter's guidebook: An issue guide for education planners and practitioners. https://sustainabledevelopment.un.org/content/documents/ 921unesco3.pdf

UNESCO. (2013). Climate change in the classroom. http://www.unesco.org/new/en/ ccesd

UNESCO. (2016). Textbooks pave the way to sustainable development (Policy Paper 28). Global Education Monitoring Report. https://en.unesco.org/gem-report/textbookspave-way-sustainable-development

UNESCO. (2018). Sustainability starts with teachers: An ESD action learning programme for secondary teacher educators in Southern Africa. http://www.unesco.org/new/ en/media-services/single-view/news/sustainability_starts_with_teachers_esd_ training_for_southe/ 
UNESCO. (2019a). Educational content up close: Examining the learning dimensions of education for sustainable development and global citizenship education. https://unesdoc.unesco.org/ark:/48223/pfoooo372327/PDF/372327eng.pdf.multi

UNESCO. (2019b). Country progress on climate change education, training and public awareness: An analysis of country submissions under the United Nations Framework Convention on Climate Change. https://unesdoc.unesco.org/ark:/48223/ pfoooo 372164

UNESCO \& UNEP [United Nations Environment Programme]. (2011). YouthXchange climate change and lifestyle guidebook. https://www.unep.org/resources/report/ youthxchange-climate-change-and-lifestyles-guidebook

Van Poeck, K., Vandenabeele, J., \& Bruyninckx, H. (2013). Sustainable citizenship and education. https://www.researchgate.net/publication/278409752_SUSTAINABLE_ CITIZENSHIP_AND_EDUCATION

Wals, A. E. J. (2010). Mirroring, Gestaltswitching and transformative social learning: Stepping stones for developing sustainability competence. International Journal of Sustainability in Higher Education, 11(4), 380-39o.

Wals, A. E. J. (2012). Learning our way out of un-sustainability: The role of environmental education. In S. Clayton (Ed.), Oxford handbook on environmental and conservation psychology. Oxford University Press.

Wamsler, C., Brink, E., \& Rentala, O. (2012). Climate change, adaptation, and formal education: The role of schooling for increasing societies' adaptive capacities in El Salvador and Brazil. Ecology and Society, $17(2)$.

Zou, J. J. (2017). Oil's pipeline to America's schools: Inside the fossil-fuel industry's notso-subtle push into K-12 education. Center for Public Integrity.

https://apps.publicintegrity.org/oil-education/ 